\title{
Research on Arrangement Design for Sailing Yacht Winch using 3D Human Simulation
}

\author{
Yeun-Hee Song", Dong-Joon Kim", Seong Rok Chang ${ }^{* *}$, Yujeong Lee ${ }^{* *}$ and Kyong-Cheol Min ${ }^{* * *}$ \\ "Department of Naval Architecture and Marine Systems Engineering, Pukyong National University, Busan, Korea \\ ${ }^{* *}$ Department of Safety Engineering, Pukyong National University, Busan, Korea \\ Department of Naval Architecture \& Ocean Engineering, Koje College
}

\section{D 휴먼 시뮬레이션을 통한 세일링 요트 윈치 배치 설계 연구}

\author{
송연희 ${ }^{*}$ 김동준 ${ }^{*}$ 장성록** 이유정 ${ }^{* *}$ 민경철 ${ }^{* * *}$ \\ *부경대학교 조선해양시스템공학과 \\ *부경대학교 안전공학과 \\ **거제대학교 조선해양공학과
}

KEY WORDS: Arrangement design 배치설계, 3D human simulation 3D 휴먼 시뮬레이션, Sailing yacht 세일링 요트, Winch arrangement 윈치 배치, Grinder 그라인더

\begin{abstract}
Unlike other leisure boats, a sailing yacht is propelled by wind power using sails that are controlled by the crew. Therefore, the ergonomic design of the equipment that the crew has to operate for sailing might be very important. However, it is difficult to find design rules and regulations for the equipment arrangement of a sailing yacht based on ergonomics. In this study, the arrangement design for the height and side plate angle of a winch for a sailing yacht was examined from an ergonomic design point of view. In a simulation, a Korean male in his 20 s was selected as a human model for a grinder. The physical load was analyzed when he was operating a winch using a 3D human simulation. The lower back load showed the highest value when using the grinder at $90^{\circ}$ and $180^{\circ}$. Based on the results for the lower back load when using the grinder with various winch heights, it is suggested that the winch height from the cockpit floor to the top of the winch should be more than $40 \%$ of the height of the human operator. In addition, according to the results for the lower back load with various horizontal distances from the body, it is suggested that the side plate angle should be less than $16^{\circ}$.
\end{abstract}

\section{1. 서 론}

최근 국내에서는 해양수산부장관배 국제요트대회 및 새만금 국제요트대회 등 다양한 요트대회가 개최되고 있으며, 2015년 해양수산부에서 해양신사업 육성과 일자리 창출을 위한 '마리 나산업 전략적 육성대책'을 발표하면서 요트에 대한 관심이 높 아지고 있다(Kim et al, 2016). 해양레저장비 중 선박으로 분류 되는 것은 크게 동력으로 추진하는 파워보트와 바람의 힘으로 추진하는 세일 요트로 나누어진다. 이 중에서 국내에서 진행된 세일 요트에 관한 연구 현황을 살펴보면 주로 조선공학적 해석 을 다루고 있다. 관련 연구로 Ji et al.(2010)은 세일링 요트의 구 조적 안전성평가에 대한 연구로 유한요소해석을 통하여 안정성 평가를 수행하였고, Shin et al.(2006)은 해양레저 선박으로서 소
형 요트의 기본구조설계 및 구조해석 기법을 제시하였다.

한편, 일반적으로 레저보트 대부분의 공간이 협소하여 인간공 학적 배치 및 사용을 위한 연구가 필수적이라 판단된다. 하지만 세일링 요트와 관련된 설계 규정에 인간공학적 고려가 일부 언 급되고 있으나, 침실 및 생활공간에 대한 고려일 뿐 윈치 등 리 깅류에 대한 인간공학적인 설계기준이 적용된 사례는 찾아보기 어렵고, 이에 대한 인간공학적 연구 또한 드문 편이다.

Kim et al.(2013a)은 세일링 요트 운항 시 발생하는 크루(Crew) 의 이동 동선을 분석하고 각각의 주요 임무에서 발생하는 자세 들을 분석하여 해당 자세의 위험성에 대한 기초연구를 수행하 였다. 또한, Kim et al.(2013b)은 수치 휴먼 모델링(Digital human modeling)의 인간공학적 분석기법을 이용하여 세일링 요트 운항 시 발생하는 작업 자세를 크게 7가지로 분류 하고, 전문가와

Received 25 January 2017, revised 31 January 2017, accepted 18 December 2017

Corresponding author Dong-Joon Kim: +82-51-629-6614, djkim@pknu.ac.kr

(C) 2017, The Korean Society of Ocean Engineers

This is an open access article distributed under the terms of the creative commons attribution non-commercial license (http://creativecommons.org/licenses/by-nc/3.0) which permits unrestricted non-commercial use, distribution, and reproduction in any medium, provided the original work is properly cited. 


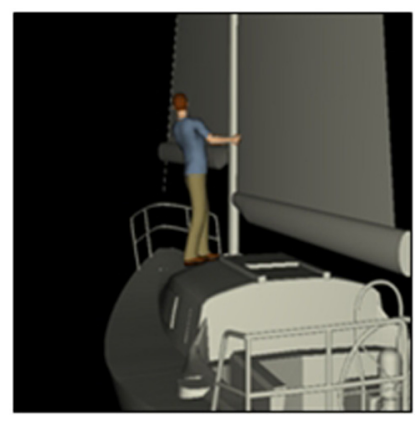

(a) Bowman

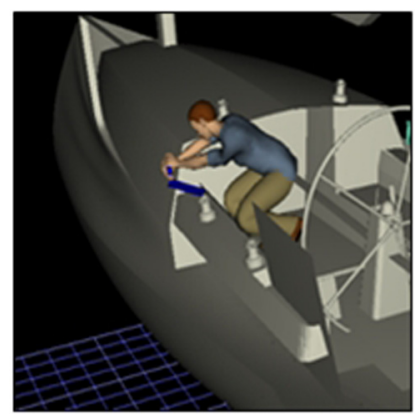

(c) Grinder

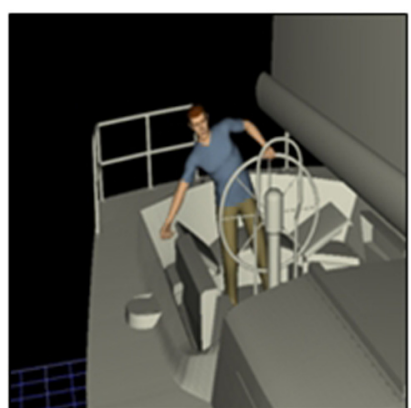

(b) Skipper

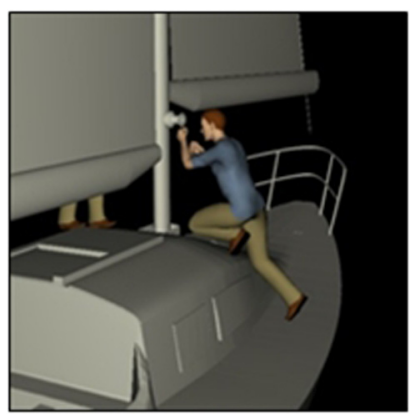

(d) Trimmer
Fig. 1 Human modeling of working posture of crews (Kim et al. 2013b)

의 인터뷰를 바탕으로 각 크루가 가장 많이 취하는 자세를 4 가 지로 축소하였다. 4 가지 자세로는 Fig. 1 에서와 같이 바우맨의 전방주시, 스키퍼의 휠조종, 그라인더의 윈치조종, 트리머의 돛 게양을 선택하였다. 수치 휴면 모델링을 이용하여 평가한 결과 4 명의 크루 중 트리머와 그라인더가 활동 범위가 넓고 작업 자 세 위험성이 높은 것을 알 수 있었다.

또한, Kim et al.(2013b)의 결과에 따르면 트리머와 그라인더 임무 중에서도 그라인더의 작업이 세일링 작업 시 일반적으로 가장 빈번히 발생하고 짧은 시간 내에 큰 힘을 요하기 때문에 트리머 보다 작업위험성이 더 높다고 분석되었다. 따라서 본 연 구에서는 그라인더의 작업에 대하여 집중적으로 연구하였다.

본 논문에서는 세일링 요트 윈치 배치 설계 기준에 대한 연구 로써, 인간공학적 분석기법을 활용하여 윈치 배치에 따른 그라 인더의 신체부하를 측정하고 윈치의 적합한 위치를 제안하고자 한다. 인체 모델링 프로그램으로는 3D 휴먼시뮬레이션 프로그 램인 Jack(Siemens, 2003)을 이용하였다. 이를 통해 윈치 배치 변 화에 따른 그라인더의 허리 부하를 측정하고 분석하여 무리한 부하가 걸리지 않도록 윈치의 최적 배치 범위를 찾고자 하였다.

\section{2. 휴먼 모델링과 허리부하 경향 분석}

\section{1 휴먼 모델링}

그라인더의 작업을 시뮬레이션하기 위해서는 먼저 휴먼 모델링 이 필요하다. 본 연구에서 휴먼 모델은 사이즈코리아 사이트 (sizekorea.kats.go.kr)의 20대 남성 표준 사이즈를 기준으로 하여, 전체 사이즈 중 $5 \% \mathrm{ile}, 50 \% \mathrm{ile}, 95 \% \mathrm{ile}$ 에 해당하는 그룹의 평균
Table 1 Size of human model

\begin{tabular}{ccc}
\hline \hline Human & Height $[\mathrm{cm}]$ & Weight $[\mathrm{kg}]$ \\
\hline $5 \%$ ile & 165 & 63 \\
$50 \%$ ile & 175.49 & 77.69 \\
$95 \%$ ile & 191.00 & 108 \\
\hline
\end{tabular}

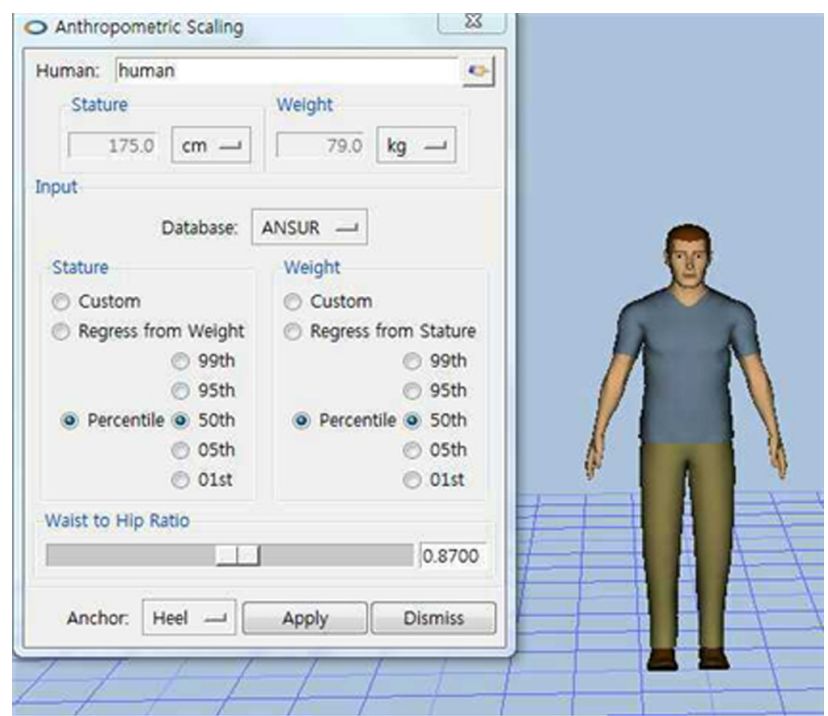

Fig. 2 Human model

사이즈를 이용하였다. 여기서 ile은 Percentile을 나타내는 단위 로, 계측치를 작은 쪽에서부터 세어 몇 \%째의 값이 어느 정도 인지를 나타내는 통계적 표시이다. 즉, $5 \%$ ile은 작업자를 큰 순 서로 정렬했을 때 작은 쪽에서 $5 \%$ 에 속하는 크기를 의미하며, 키는 $165 \mathrm{~cm}$, 몸무게는 $63 \mathrm{~kg}$ 에 해당된다. $5 \%$ ile, $50 \%$ ile, $95 \%$ ile에 해당하는 신체 사이즈는 Table 1과 같이 결정하였다.

본 연구에서는 시뮬레이션을 위해 Jack 프로그램을 이용하였 다. Jack 프로그램은 설계에 가상인력을 포함시키고 인적 요인 및 인체공학 해석을 수행할 수 있는 휴먼 시뮬레이션 도구로 인간공학 연구에서 널리 사용되고 있다. Table 1에 나타나 있는 모델을 Jack 프로그램을 이용하여 Fig. 2와 같이 Human 모델을 생성하였다.

\section{2 그라인더의 작업각도에 따른 허리부하 경향 분석}

그라인더의 윈치 작업에서 최대로 허리부하가 걸리는 각도를 파악하기 위하여, Fig. 3 과 같이 윈치 작업 각도를 $0^{\circ}, 90^{\circ}, 180^{\circ}$ 로 구분하여 허리부하를 측정하였다. $0^{\circ}, 90^{\circ}, 180^{\circ}$ 의 세 가지 각 도를 택한 것은 한 바퀴 윈치를 회전시키는 동안 부하가 변화 하는 대표적인 각도로 판단하여 선정하였다. 그리고 허리부하 는 NIOSH(National institute of occupational safety \& health, 미국 국립산업안전보건연구원) Lifting equation과 동일한 기준을 적용 하기 위하여 L5(요추5번)를 중심으로 해석하였다.

또한, 각도 별 윈치 높이에 따른 허리부하에 미치는 영향을 분석하기 위하여, 윈치 높이를 대상 선박의 높이 기준으로 $10 \%$ 씩 이동하여 분석하였다. 아울러 신장에 따른 허리부하의 경향 을 알아보기 위하여 앞서 설정한 휴먼 모델링 3그룹에 대하여 


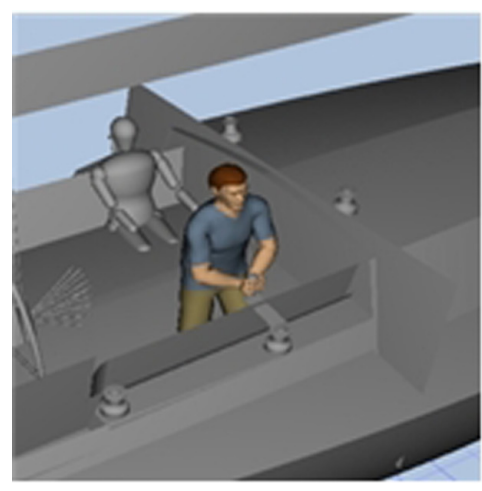

(a) $0^{\circ}$ work posture

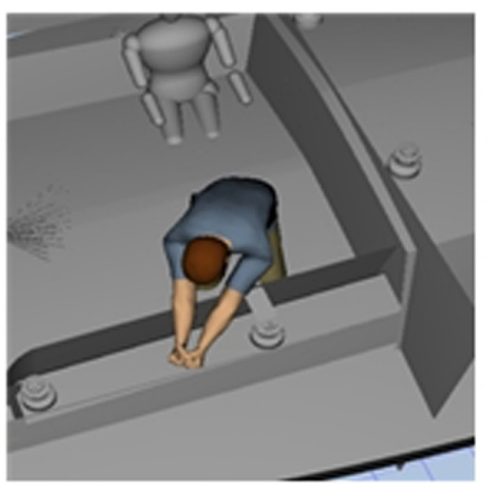

(b) $90^{\circ}$ work posture

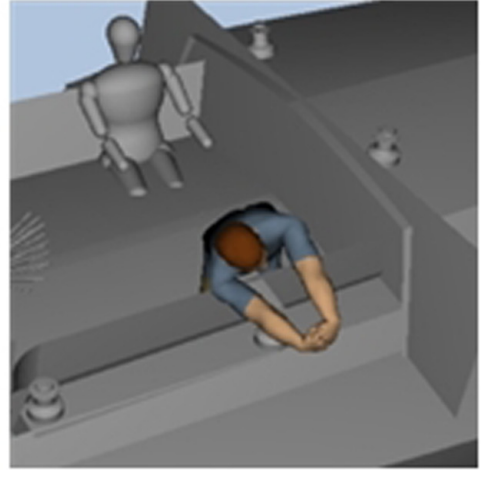

(c) $180^{\circ}$ work posture

Fig. 3 Work posture by winch degree of grinder

상기 연구를 수행하였다.

시뮬레이션을 통해 측정한 허리부하 결과는 Table 2와 Fig. 4 와 같다. 여기서 허리부하의 값은 힘 단위를 갖는다. Upper $10 \%$ 와 Under $10 \%$ 는 Deck 높이를 $10 \%$ 씩 상- 하로 이동시킨 것을 의미하며, 그에 따른 윈치 높이의 변화는 기준 높이에서 $10 \%$ 씩 감소- 증가시킨 것을 의미한다. 즉, 데크(Deck) 높이가 Upper $10 \%$ 일 경우, 윈치 높이는 $10 \%$ 감소한다.

Fig. 4에 따르면 작업 각도별로는 신장과 무관하게 $0^{\circ}$ 보다 $90^{\circ}$ 및 $180^{\circ}$ 에서 허리부하가 크게 나타남을 알 수 있었다. 허리부하 절대값의 차이는 있지만 모든 그룹의 그래프에서 윈치 작업각

Table 2 Low back compression force( $\mathrm{N})$ on grinder working by human model size and winch handle position

\begin{tabular}{ccccc}
\hline \multirow{2}{*}{ Human } & Winch height & \multicolumn{3}{c}{ Position of winch handle } \\
\cline { 3 - 5 } & & $0^{\circ}$ & $90^{\circ}$ & $180^{\circ}$ \\
\hline \multirow{2}{*}{$5 \%$ ile } & upper 10\% & 1,357 & 1,539 & 1,480 \\
& base H. & 1,002 & 1,549 & 1,580 \\
& under $10 \%$ & 892 & 1,407 & 1,502 \\
\hline \multirow{2}{*}{$50 \%$ ile } & upper $10 \%$ & 1,724 & 1,957 & 1,871 \\
& base H. & 1,451 & 1,929 & 1,994 \\
& under $10 \%$ & 1,419 & 1,841 & 1,871 \\
\hline \multirow{2}{*}{ 95\%ile } & upper $10 \%$ & 2,445 & 2,564 & 2,444 \\
& base H. & 2,361 & 2,618 & 2,593 \\
& under $10 \%$ & 2,060 & 2,485 & 2,470 \\
\hline
\end{tabular}

도가 $90^{\circ}$ 와 $180^{\circ}$ 일 경우 $0^{\circ}$ 에 비해 큰 부하가 걸리는 경향이 있 음을 알 수 있었다. Fig. 3 에서 볼 수 있듯이 $90^{\circ}$ 의 경우 비대칭 작업과 허리굽힘으로 인한 허리 회전이, $180^{\circ}$ 의 경우 허리가 더 많이 굽어진 것이 허리부하에 영향을 미쳤을 것으로 판단된다. 그라인더의 신장에 따른 허리부하는 작업각도와 무관하게 전 체적으로 증가하였다. 하지만 5\%ile와 $50 \%$ ile 사이에서 변화는 크지 않으나, $50 \%$ ile에서 $95 \%$ ile 사이에서는 크게 증가하였다. 이는 윈치의 기준위치가 고정되어 있으므로 신장이 커질 때 상 대적으로 윈치 높이는 낮아지게 된다. 따라서 신장의 변화 보다 는 윈치의 상대적 높이변화가 작업 시 허리부하에 크게 영향을 미치는 것을 알 수 있었다.

윈치 높이의 변화에 따른 허리부하는 $5 \%$ ile의 경우 작업각도 $0^{\circ}$ 에서 기준높이와 Under $10 \%$ 보다 Upper $10 \%$ 일 경우 높게 나 오고, $50 \%$ ile의 경우 유사한 경향을 보이나 절대 값의 차이는 줄어들었다. $95 \%$ ile의 경우 작업각도 $0^{\circ}$ 에서 두 그룹과는 달리 기준높이의 값이 Upper $10 \%$ 와 같이 Under $10 \%$ 보다 높게 나왔 다. 여기서도 윈치의 상대적 높이가 어느 범위 이하의 값이 되 면 $0^{\circ}$ 작업에서도 허리부하가 증가되는 것을 알 수 있었다.

\section{3. 윈치 높이 및 거리변화에 따른 허리부하 분석}

\section{1 윈치 높이 변화에 따른 허리부하 분석}

앞의 결과에 따르면 상대적 윈치 높이 변화에 따라서 허리부 하가 달라지는 것을 알 수 있었다. 따라서 윈치 높이를 $50 \mathrm{~mm}$ 씩 상-하로 변화를 주어 윈치 제어 작업 시 허리부하를 분석하였

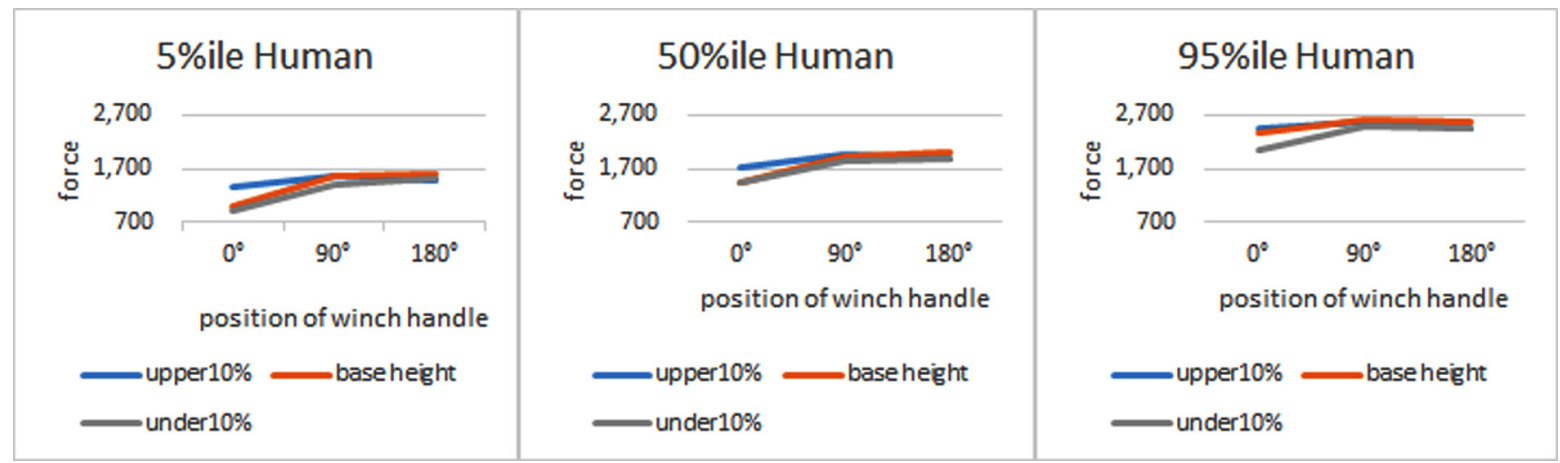

Fig. 4 Trend analysis of load on each human model 


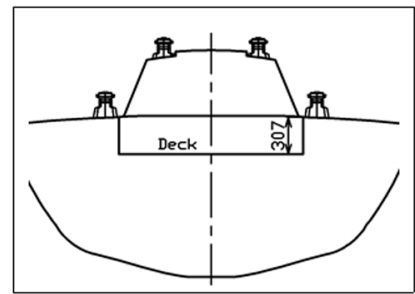

Move deck 200mm upwards

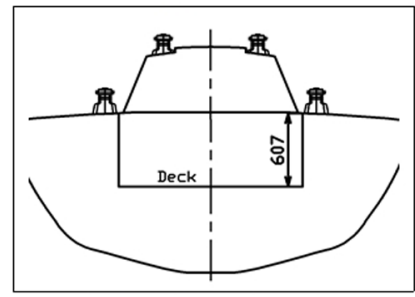

Move deck 100mm downward

Fig. 5 Cases of deck height

다. 이를 위하여 윈치 작업 각도는 큰 부하가 걸리는 것으로 판 단되는 $90^{\circ}$ 로 고정하고, 윈치 작업자는 평균 $(50 \%)$ 체형으로 선 택하여 시뮬레이션을 수행하였다.

윈치 높이 변화에 따른 허리부하 분석 시뮬레이션의 조건은 다음과 같다.

- 50\%ile 인체모델로 고정

- 윈치작업 위치를 $90^{\circ}$ 로 고정

- Fig. 5 과 같이 윈치 높이는 $50 \mathrm{~mm}$ 씩 상하로 변화

- 윈치높이 $(\%)$ 는 $\frac{\text { 윈치 } T \text { 높이 }}{\text { 표준체형작업자의키 }(175 \mathrm{~cm})}$ 로 계산하였다.

- 윈치 $\mathrm{T}$ 높이는 선체 데크에서 윈치상부까지 측정한 높이

Fig. 6은 Jack 프로그램을 이용하여 윈치 작업 시 크루에 걸리 는 허리부하를 측정하는 예이다.

윈치 높이 변화에 따른 허리부하를 측정한 결과를 종합하면 Table 3 과 Fig. 7 과 같다. $175 \mathrm{~cm}$ 신장의 작업자를 기준으로 바닥 에서부터 윈치 높이가 $65 \mathrm{~cm}(37.1 \%)$ 이하일 경우 허리부하가 $1600 \mathrm{~N}$ 보다 크게 나타나는 것을 알 수 있었고, 윈치 높이 $87.5 \mathrm{~cm}$ $(50 \%)$ 이상에서는 허리 부하가 급격하게 줄어드는 경향을 알 수 있었다.

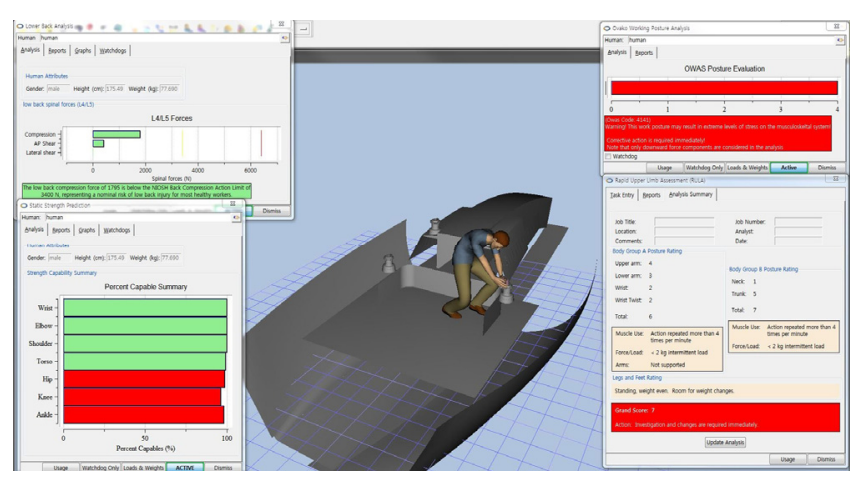

Fig. 6 Analysis of work posture by 3D human simulation program according to changing deck height
Table 3 Alteration of low back compression force by deck height change

\begin{tabular}{c|c}
\hline \hline Winch height[\%] & Low back force $[\mathrm{N}]$ \\
\hline 28.6 & 1795 \\
31.4 & 1742 \\
34.3 & 1733 \\
37.1 & 1610 \\
40.0 & 1575 \\
42.9 & 1560 \\
45.7 & 1396 \\
48.6 & 1525 \\
51.4 & 1380 \\
54.3 & 1109 \\
57.1 & 1049 \\
60.0 & 948 \\
62.9 & 675 \\
\hline
\end{tabular}

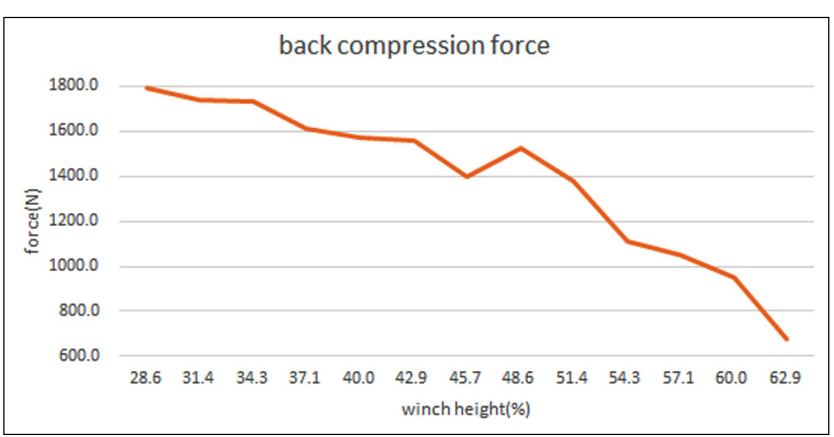

Fig. 7 Alteration of low back compression force by deck height change

윈치 높이에 따른 허리부하의 위험성을 판단하는 정확한 평 가기준을 찾고자 하였으나, 직접적으로 적용할 만한 것을 찾기 어려웠다. 한편, NIOSH lifting equation(들기작업지침)에 따르면 들기 작업을 할 때 요추(L5/S1)디스크에 $650 \mathrm{~kg}$ 이상의 생체역학 적 부하가 부과되는 작업은 작업자에게 매우 위험하며, 또한 이 를 초과하면 대부분의 사람 허리에 무리가 가해지게 되는 안전 작업하중으로는 생체역학적 부하 $350 \mathrm{~kg}(3400 \mathrm{~N})$ 이하로 명시되어 있다(Jäger and Luttmann, 1999). 본 연구의 그라인더 윈치조작은 들기 작업과는 다르나 유사한 자세를 취하기 때문에 이 기준을 고려하였다.

이 기준은 작업의 반복 횟수, 작업 시간 및 작업 형태에 따라 안전작업하중이 감소할 수 있다. 반복 횟수에 관한 감소기준에 대한 연구로는 Chaffin 등이 저술한 Occupational biomechanics (Chaffin et al., 1999)이 있으며, 직업적으로 10회 이상 반복 작업 의 경우 안전작업하중의 $30 \%$ 이하로 적용하는 것을 권고하고 있다. 또한 반복 횟수와 시간에 관한 감소기준에 대한 연구로는 $\operatorname{Garg}(1976)$ 및 Snook and Ciriello(1991)이 있다. 이 연구에 따르 면 에너지 소모량을 고려하여 2시간 이상 작업일 경우 분당 3 회의 작업 시 작업 허용량은 적정 작업량의 $55 \%$ 정도이며, 분 당 4 회의 작업 시는 $45 \%$ 정도임을 밝혔다. 그리고 작업 형태에 
관한 감소기준에는 $\operatorname{Snook(1978)ㅇㅢ~ㅇㅕㄴㄱㅜㅇㅔ~ㅇㅢㅎㅏㅁㅕㄴ,~ㅂㅣㄷㅐㅊㅣㅇ~ㅈㅏㄱㅇㅓㅂ~}$ 의 경우 30 경사 시 약 $90 \%$ 로 경감한 하중을 적용하는 것을 권 고하고 있다.

요트 항해 시 방향을 전환하거나 최적의 세일 형상으로 수정 하기 위해 세일트림(Sail trim)을 할 때 주로 윈치작업을 하며, 최악의 기상 상황 이거나 레이싱을 수행할 경우 방향전환 및 세일트림은 빈번히 일어난다. 윈치작업은 윈치를 회전시키기 위하여 허리를 굽히고 팔을 이용하여 윈치 핸들을 회전시키는 작업을 의미하며, 이러한 윈치 작업의 반복횟수와 시간에 대한 기준을 찾기 위해 작업환경을 가정하였다. 통상적으로 요트는 2 시간 이상의 항해를 하며, 극한의 기상 상황 및 레이싱 등을 가 정할 때 시간당 최대 15 세트 정도의 윈치작업을 수행하게 된다.

윈치작업 시 숙련자의 경우 적절한 순간에 짧은 시간동안 수 행하므로 보통 한 세트에 5 7회 회전시키는 작업을 하며, 초보 자의 경우 경험이 많지 않기 때문에 한 세트에 최대 20회까지 회전을 하게 된다. 따라서 그라인더의 윈치작업을 한 세트에 최 대 14 15회 회전시키는 작업으로 가정한다. 여기서 윈치작업은 회전시키는 연속 작업이나 본 연구에서는 1 회 회전작업 당 허 리굽힘자세를 1 회 취하는 것으로 간주하였다.

따라서 윈치작업은 평균 14 15회 회전작업을 15 세트 정도 수 행하므로 한 시간당 최대 210 225회의 허리굽힘자세를 취하는 것으로 가정하였고, 이는 1 분당 3.5 3.7회의 작업 횟수를 가지게 된다. 작업시간과 횟수 기준인 $\operatorname{Garg}(1976)$ 및 Snook and Ciriello (1991)의 결과를 적용하면 작업 허용량은 안전작업하중의 약 $50 \%$ 이다.

또한 윈치 손잡이가 그라인더의 신체를 기준으로 $90^{\circ}$ 와 $270^{\circ}$ 의 위치일 경우 비대칭 작업이 발생한다. 이작업시 허리가 $30^{\circ}$ 정도 비틀어져있다고 가정할 때, Snook(1978)의 결과에 따라 안 전작업하중은 $10 \%$ 경감하여야한다.

최종적으로 반복횟수, 시간 그리고 작업형태를 고려 할 때 가 정된 극한상황에서의 요트 항해 시 경감된 안전작업하중비율은 약 $45 \%$ 이다. 따라서 안전작업하중 $3400 \mathrm{~N}$ 의 $45 \%$ 인 $1530 \mathrm{~N}$ 이하 의 허리부하가 적당하다고 판단된다. 그러므로 Table 3 으로부터 적절한 윈치 위치는 $175 \mathrm{~cm}$ 신장의 작업자를 기준으로 하였을 때 바닥으로부터 윈치 윗면까지 높이는 $40 \%$ 이상이 적당하다 고 판단되며, 이것을 실제 거리로 환산 할 경우 바닥으로부터 약 $70 \mathrm{~cm}$ 이다.

\section{2 윈치와 작업자간의 거리 변화에 따른 허리부하 분석}

윈치와 작업자간의 거리가 허리 부하에 미치는 영향을 파악 하기 위하여 윈치 높이를 고정하고 윈치가 위치한 선측 벽면을 Fig. 8과 같이 선측외판으로 각도를 변화시켰다. 이에 따라 윈치 의 위치 또한 선측 외판 각도에 따라서 초기위치보다 선측외판 쪽으로 멀어지게 된다. 윈치 작업자의 신장을 평균 $(50 \%)$ 체형으 로 고정하고 윈치 위치 $90^{\circ}$ 에서 작업자 허리부하를 분석하였다.

윈치와 작업자간의 거리 변화에 따른 허리부하 분석 시뮬레 이션의 조건은 다음과 같다.

- $50 \%$ ile 인체모델 고정

- 윈치작업 위치를 $90^{\circ}$ 로 고정

- 윈치 높이는 $40 \%$ 근처로 고정

- 선측각도는 선체 외판으로 벌어지는 각도를 측정 $\left(0^{\circ} \sim 20^{\circ}\right)$

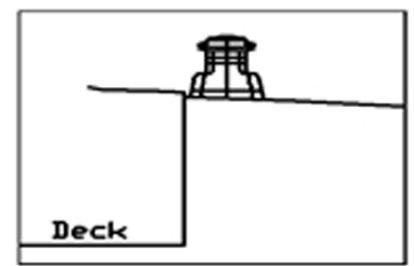

Side plate angle $0^{\circ}$

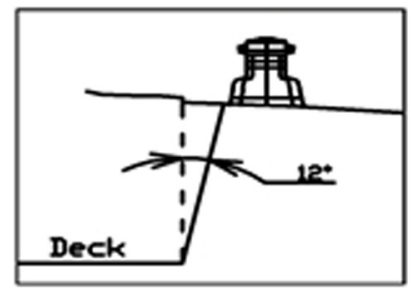

Side plate angle $12^{\circ}$

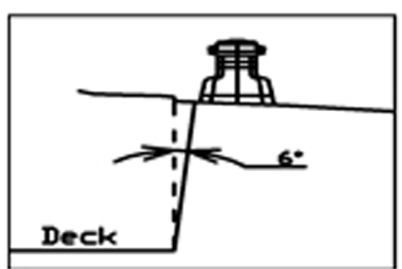

Side plate angle $6^{\circ}$

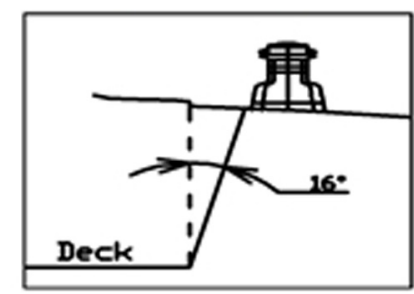

Side plate angle $16^{\circ}$
Fig. 8 Degree change of side plate

- 선측이 기울어짐에 따라 윈치 위치도 선측 외판 쪽으로 이동

- 선체의 경사는 고려하지 않음

시뮬레이션을 통하여 선측각도 변화에 따른 결과를 종합하면 Table 4와 Fig. 9와 같다.

Fig. 9의 그래프 경향을 살펴보았을 때 $0^{\circ}$ 에서 $10^{\circ}$ 까지는 완만

Table 4 Alteration of low back compression force by change of side plate degree

\begin{tabular}{c|c}
\hline \hline Degree $\left[^{\circ}\right]$ & Low back force[N] \\
\hline $0^{\circ}$ & 1575 \\
$2^{\circ}$ & 1569 \\
$4^{\circ}$ & 1560 \\
$6^{\circ}$ & 1559 \\
$8^{\circ}$ & 1546 \\
$10^{\circ}$ & 1540 \\
$12^{\circ}$ & 1484 \\
$16^{\circ}$ & 1567 \\
$20^{\circ}$ & 1664 \\
\hline
\end{tabular}

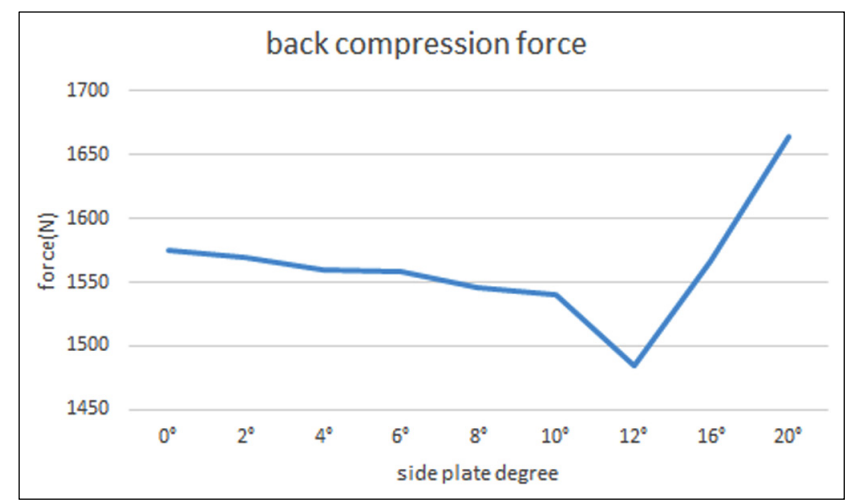

Fig. 9 Alteration of low back compression force by change of side plate degree 
한 기울기로 허리부하가 줄어드나 $12^{\circ}$ 이후에는 각도 변화에 따 른 허리부하가 급격하게 증가하는 것을 볼 수 있다. 그러므로 $12^{\circ}$ 근처가 최적 위치라고 판단된다. 또한 선측각도 $16^{\circ}$ 이상일 경우 작업자 허리부하가 급격하게 증가할 것으로 예상되어, 이 상의 선측각도는 곤란하다고 판단된다. 각도까지 위치를 실제 거리로 환산 할 경우 $12^{\circ}$ 경우는 약 $22 \mathrm{~cm}$ 이며, $16^{\circ}$ 경우 약 $26 \mathrm{~cm}$ 이다. 이는 생체역학이나 심물리학적 연구에서 제시된 결과인 작업 시 작업자와 물체 사이 최적거리 $25 \mathrm{~cm}$ 와 거의 일치하는 것으로 나타났다.(Snook, 1978; Chaffin et al., 1999)

\section{4. 결 론}

항해 시 빈번히 발생하며 작업부하가 가장 커서 작업위험성 이 높다고 판단되는 그라인더의 윈치작업 시 무리한 신체부하 를 유발하지 않는 윈치의 적정 위치를 찾고, 그것의 배치 기준 을 제시하기 위하여 윈치작업을 $3 \mathrm{D}$ 휴먼 시뮬레이션을 이용하 여 분석하였다.

이에 첫 번째로 윈치작업 위치를 $0^{\circ}, 90^{\circ}$ 그리고 $180^{\circ}$ 로 구분 하고, 두 번째로 윈치를 기준위치보다 수직으로 $\pm 10 \%$ 씩 이동하 고, 세 번째로 그라인더의 신장을 3그룹으로 나누어 각 상황에 대하여 분석하였다. 그 결과, 각각의 신장에 대한 작업 위치 및 윈치 높이에 따른 허리부하 절대값의 차이는 있지만, 모든 그룹 이 $90^{\circ}$ 와 $180^{\circ}$ 작업에서 큰 부하가 걸리는 경향을 알 수 있었다. 또한, 그라인더의 신장에 따른 허리부하는 작업각도와 무관하 게 전체적으로 증가하였다. 이는 윈치의 기준위치가 고정되어 있으므로 신장이 커질 때 상대적으로 윈치 높이는 낮아지게 되 어 윈치의 상대적 높이변화가 작업 시 허리부하에 크게 영향을 미치는 것을 알 수 있었다.

따라서 그라인더의 신장을 $50 \%$ ile로, 윈치 작업 위치를 $90^{\circ}$ 로 고정한 후 윈치 높이를 대상선박을 기준으로 $50 \mathrm{~mm}$ 씩 상 - 하로 변화하여 허리부하를 분석하였다. 그 결과 $175 \mathrm{~cm}$ 신장의 작업 자를 기준으로 하였을 때 윈치 높이는 $40 \%$ 이상 되는 곳에 놓 이는 것이 적당하다고 판단된다. 또한 앞선 시뮬레이션과 같은 조건에서 윈치의 위치를 상- 하 방향이 아닌, 선측각도를 변화 시켜 윈치가 선측으로 멀어 질수록 그라인더에 걸리는 허리부 하를 분석하였다. 그 결과 약 $175 \mathrm{~cm}$ 신장의 작업자를 기준으로 선측외판을 $16^{\circ}$ 이상으로 하는 것은 허리에 과도함 부담을 줄 것으로 판단된다.

본 연구는 실제 작업자의 작업 부하를 직접 측정하지 않고, $3 \mathrm{D}$ 휴먼 시률레이션을 이용하여 경제적이며, 시간과 공간의 제 약을 받지 않고 시뮬레이션을 수행할 수 있었다. 그러나 시뮬레 이션은 작업자의 실제동작을 섬세하고 정확하게 구현하는데 어 려움이 있었다. 또한 본 연구는 선체가 항해 중 움직임이 있는 상태가 아닌 정지한 상태를 기준으로 허리부하를 측정한 것으
로 향후 선체운동에 따른 하중을 고려한 추가 연구가 필요할 것으로 생각된다.

\section{후기}

이 논문은 부경대학교 자율창의학술연구비(2016년)에 의하여 연구되었음.

\section{References}

Chaffin, D.B., Andersson, G., Martin, B.J., 1999. Occupational Biomechanics. $3^{\text {rd }}$ Edition, Wiley, New York.

Garg, A., 1976. A Metabolic Rate Prediction Model for Manual Materials Handling Jobs. Ph.D Dissertation, University of Michigan.

Ji, S.H., Roh, J.S., Kang, S.W., Kim, H.W., Kim, M.H., 2010. Structural Safety Evaluation of 40 Feet Sailing Yacht by Computational Structure Analysis. Journal of the Society of Naval Architects of Korea, 47(5), 703-708.

Kim, D.J., Oh, H., Lee, Y., Chang, S.R., 2013a. Fundamental Study for Ergonomic Design of Sailing Yacht. Journal of the Korean Society of Safety, 28(2), 73-77.

Kim, D.J., Ko, C.G., Lee, Y., Chang. S.R., 2013b. Application of Digital Human Modeling for Design of Yacht. Journal of the Ergonomics Society of Korea, 32(5), 475-480.

Kim, I.C., Oh, H.J., Kim, D.,W., 2016. A Study on the Development of the Safe Navigation Route for a Sailing Yacht Focused on Geomundo(Port Hamilton). Journal of the Korean Society of Marine Environment \& Safety, 22(2), 174-180.

Jäger. M., Luttmann A., 1999. Critical Survey on the Biomechanical Criterion in the NIOSH Method for the Design and Evaluation of Manual Lifting Tasks. International Journal of Industrial Ergonomics, 23(4), 331-337.

Shin, J.G., Lee, J.Y., Lee, J.H., Van, S.H., Lee, S.H., Yoo, J., 2006. A Study on the Structural Design and Structural Analysis for Small Yacht. Journal of the Society of Naval Architects of Korea, 43(1), 75-86.

Siemens, P.L.M., 2003. Software, 2009. Tecnomatix Jack, Siemens PLM Software, Plano, TX.

Snook, S.H., 1978. The Design of Manual Handling Tasks. Ergonomics, 21, 963-985.

Snook, S.H., Ciriello, V.M., 1991, The Design of Manual Handling Tasks: Revised Tables of Maximum Acceptable Weights and Forces. Ergonomics, 34, 1197-1213. 